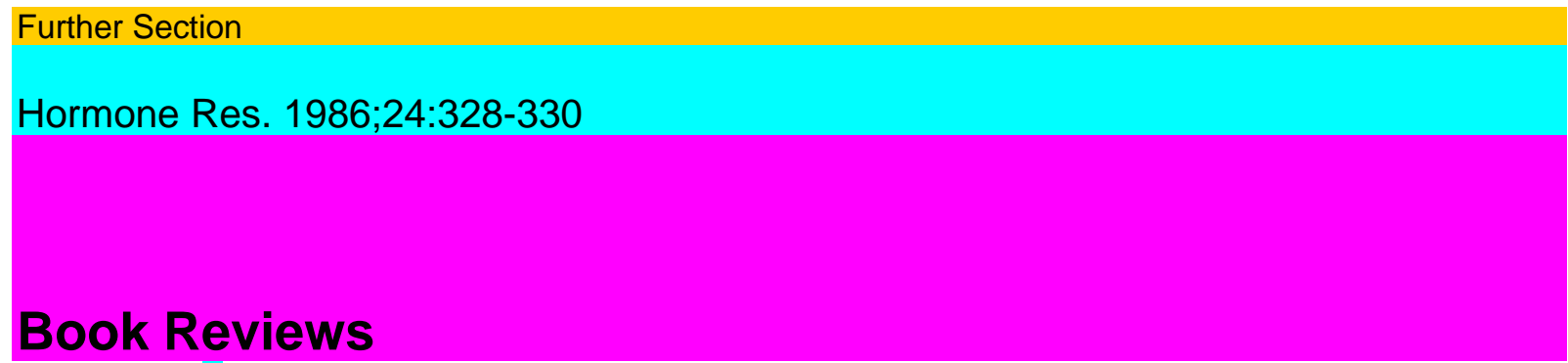

\title{
R.G. Gosden
}

Biology of Menopause

The Causes and Consequences of Ovarian Ageing Academic Press, London 1985 XIV + 188 pp.; US\$ 37.50/E 29.00 ISBN 0-12-291850-9

Most women will spend over one third of their life after the menopause. It has therefore not to be emphasized that the causes and consequences of ovarian ageing are of central interest for all those working in the field of reproductive endocrinology. However, the professional scientist and clinician is faced with a widely dispersed literature. Recent and competent reviews are lacking. This monography has been written for research workers, clinicians and students interested in the biology of the ageing reproductive system. Its author made a life study of ovarian failure and is thoroughly acquainted with the multiple aspects of its causes and consequences. This book is primarily concerned with human biology. Where evidence in the human is lacking, detailed accounts of animal research are presented. For better understanding of the actual concepts, several topics are preceded by a historical introduction.

The first part of the monography deals with terminology, historical recognition and symptomatology of menopause. It views the influence of genetic and socioeconomic factors, nutrition, body size and composition, marital status, parity and contraceptive practice, smoking, and diseases and drugs at menopause. Finally, the aptitude of animal models for the study of ageing in the human reproductive system is discussed. Chapter 2 summarizes the actual knowledge of production, metabolism and clearance of oestrogen before and after menopause. Chapter 3 deals with the different aspects of the follicular store, namely the formation of oocytes and follicles, follicular growth, the recruitment of ovulatory follicles, follicular dynamics throughout life and the possible causes of precocious ovarian failure. Chapter 4 presents the concept of physiological regulation of the menstrual cycle and the pattern of cyclical activity in non-primates, primates and human. The aetiology of acyclicity and its importance for the human menopause is discussed. The next chapter (5) highlights the problem of fertility/subfertility in middle age and views the actual data on fertility and abortion rate. The significance of errors of oogen-esis and embryo development, chromosomal anomalies and changes in the maternal environment as factors in the loss of fertility is shown. Chapter 6 summarizes the somatic, metabolic and behavioural consequences of menopause. It views the causes and consequences of the atrophy of epithelia, of autonomic nervous disturbances, of the demineralization of bone and of the intermediary metabolism. This chapter ends with some wellselected remarks on the effects of age on sexual behaviour. The seventh and last chapter 'The Hormone Replacement Therapy Controversy' intends to precise the indications and the contraindications for and the alternatives to hormone replacement therapy. The author proceeds by opposing the biological consequences of ageing to the risks and benefits of oestrogen replacement therapy. The topics 'contraception in middle age', 'subfertility', and 'hormone replacement therapy' are tackled primarily from the scientific standpoint, but these sections, too, are full of essential data leading the reader to practical clinical consequences. 
In conclusion, this book is a timely summary of the present knowledge in the fascinating area of the biology of menopause. This monography can be recommended to all those looking for a concise and well-written survey of the causes and consequences of ovarian ageing. For those who wish to enter the field, it is an excellent introduction.

M. Birkhäuser, Basel

R.A. Bradshaw, G.N. Gill

Evolution of Hormone-Receptor Systems

UCLA Symposia on Molecular and Cellular Biology New Series, vol. 6 Liss, New York 1983

XXI + 503 pp.; E 67.00 ISBN 0-8451-2605-9

'Evolution of hormone receptor systems', the proceedings of the corresponding UCLA

Symposium held at Squaw Valley, California, in 1982, contains 40 chapters and 8 workshop reports written by more than

Book Reviews

329

100 authors. The conference focussed mainly on membrane receptors, such as receptors for growth factors, peptide hormones, catecholamines and acetyl choline, and to a lesser extent on receptors for steroid hormones and toxins. The topics covered various aspects, such as (1) isolation and characterization of receptors, (2) receptor properties, (3) receptor antibodies, (4) receptor kinase activity, (5) receptor inter-nalization, (6) nuclear receptors and (7) signalling mechanisms. The individual chapters are written in the form of original publications and about two thirds of them have also been published in the Journal of Cell Biology in 1982/83. The workshop reports are brief accounts on the presentations given and contain the relevant literature citations. The book is a rich source of information on various aspects of receptor research, but gives little new information on the topic promised in the title, namely receptor evolution. This is not surprising since at present little is known about the ontogeny and phylogeny of hormone receptors. This may change in the future when more receptor genes have been characterized. A. Eberle, Basel

J.C. Somogyi

Influence of Modern Style of Life on Food

Habits of Men

Bibliotheca Nutritio et Dieta, vol. 36

Karger, Basel 1985

VIII + 92 pp.

SFr. 83.- I DM 99.-/US\$ 35.50/E 26.00

ISBN 3-8055-4152-X

This book contains a series of 10 papers which were presented during a symposium, held in Lloret de Mar, October 26, 1984. The first two German papers evaluated psychological factors influencing nutritional behaviour, and assessed the influence of various colours affecting appetite control. A further chapter in German by Krug et al. described the effects of cookery advices and diet information on nutritional practices. The rest of the papers are written in English; Dr. P. Mann's report described the influence of international trade on nutritional habits in industrialised countries. Dr. Astier-Dumas from Paris reported the influence of tourism on food choice. Dr. Norom described ways and means of influencing nutritional behaviour in Norway. Dr. Varela from Madrid reported the effect 
of urbanization and of the nutritive status on food habits in the Spanish population. Dr. Stare described food fallacies and food faddism, and the editor. Dr. J.C. Somogyi, wrote an imaginative report on nutrition by the year 2000. The booklet finishes with an interesting chapter on current life styles and nutritional behaviour in Italy (Dr. Alberti-Fidanza).

The book reveals new aspects in the science of nutrition. It is stimulating, and highly recommended for researchers and clinicians interested in nutrition.

U. Keller

Vincent P. Hollander

Hormonally Responsive Tumors

Academic Press, London 1985 XVIII + 558 pp.; US\$ 68.00/E 59.00 ISBN 0-12-35260-8

As put in the preface it is the challenge of the responsive tumor cell which inspired this volume planned to catalyze a synthesis of diverse knowledge.

The book is divided into a basic science and a clinical section. Although this division is somewhat artificial it is the expression of the idea of the book to present models of the transition from basic laboratory observations to the design of treatment regimens.

The book concentrates on tumors responsive to steroid hormones, i.e. breast and prostatic cancer, endometrial cancer, adrenocortical cancer as well as leukemia and lymphomas. In addition, the role of pro-lactin is discussed in several chapters, and the effects of stimulation of thyroid cancer are dealt with.

A wealth of information is given on the structure of steroid hormone receptors and the subunits in normal and neoplastic cells, on differences of the informa-tion-transduction by steroid hormone binding between normal and neoplastic cells, on the role of cAMP and cGMP in the control of mammary and adrenocortical tumor cell growth and proliferation, on proteins released by cancer cells as a result of estrogen binding, and on the regulation of steroid hormone receptors. Chapters on detection techniques of hormone receptors are included, i.e. chromatofocusing, high-performance isoelectric focusing and morphologic (histochemical) methods for detection of steroid-binding sites in human neoplasia.

Fortunately, this book concentrates on basic biochemical and morphologic information concerning hormone receptors and on large avenues of clinical

330

Book Reviews

treatment. This is the way to go in order to contribute to the progress of knowledge on the biologic behavior of tumor cells and on the treatment of human cancer. This book can be recommended to the oncologist dealing with the treatment of patients, to laboratory workers as well as to newcomers in the field. P.U. Heitz, Basel

A.N. Schechter, A. Dean

The Impact of Protein Chemistry on the

Biomedical Sciences

Academic Press, Orlando 1984 XXIX + 415 pp.; US\$ 55.00 I E 42.50 ISBN 0-12-622780-2

This volume contains the proceedings of a symposium organized in honour of the sixty-fifth birthday of Christian B. Anfinson (NIH), Nobel laureate of 1972 and one of the most eminent protein chemists of the past 30 years. The 27 chapters written by his former students and collaborators give the whole spectrum of areas on which Anfinson's work had an impact. The book is divided into five sections: a historical one, a section on protein chemistry, one on immunology, one on metabolism and endocrinology and finally one on genetics. The protein 
section contains chapters about peptide chemistry and muscle contraction (Harrington), serum albumin (Peters), hydrogen exchange

in proteins (Hvidt), protein folding (Taniuchi), cyclic peptides (Izumiya), affinity labelling (Wilchek), neuro-physins (Chaiken), nucleases (Furie). The immunology section consists of chapters by Dreyer (molecular evolution and antibody formation), Givol (antibody-combining site and its genes), Sela (protein conformation and antibody function), Arnon (antigenic determinants and synthetic vaccines), Sachs (nuclease as antigen), Fuchs (acetylcholine receptor antibodies), Haber (antibodies as drugs). The endocrinology section contains contributions on lipoproteins and atherosclerosis (Steinberg), protein chemistry and cardiology (Katz), regulation of cyclic nucleotide metabolism (Vaughan), adenylate cyclase in the adrenal cortex (Ontjes), human chorionic gonadotropin (Can-field) and a very personal presentation on affinity chromatography by Cuatrecasas. Finally, the genetics section consists of chapters by C. Epstein (early embryonic development), H. Epstein (muscle development), Zoon (interferon) and Potts (parathyroid hormone). This list shows the wide range of topics and a heterogeneity which is typical for a festschrift. The personal and historical character of most papers may limit the audience of the book to those interested in a survey on the state of modern protein chemistry, as illustrated by the outstanding contributions of Anfinson and his former students. Most chapters are very well written, and the book is a rich source of information.

A. Eberle, Basel 